\title{
THE FOREIGN POLICY OF THE USA: THE USA - RUSSIA CONTRADICTIONS IN THE UN SECURITY COUNCIL
}

\begin{abstract}
The article analyzes the priorities of the US' foreign policy. It is envisaged that the formation of the new system of international relationships of the USA did not only tend to keep hegemony, but it also tended to strengthen its position in the regions of the world which are economically developed and strategically important. The priorities of the US' foreign policy are to get a foothold in the former Silk Way roots connecting the Atlantic and the Pacific oceans and take control over the central communication system of the Eurasia, expansion of the NATO towards the East. The USA supports the idea of Germany and Japan being the permanent members of the Security Council for securing the US security in EU and in the Far East.

Currently, the US interests in Asia find themselves in a conflict with those of any country tending to get domination in the region, especially of Russia. Given the USA and Russia using veto power against the decisions of the UN for the benefit of the own geopolitical interests, making inputs to the other government's internal affairs, violating the international law norms, the weakness of the UN on resolving the member nations conflicts may lead to the collapse of this organization as well. Recently the USA supports the defense of the sovereignty right of the UN states and having reforms in the organization with this purpose.
\end{abstract}

Key words: the US foreign policy, diplomatic and economic relationship, the veto power.

In the formation of the new system of international relationships the USA does not only tend to keep hegemony, it also tends to strengthen its position in the regions of the world which are economically rich and strategically important.

One of the strategic targets of the USA is to get strengthen in the former Silk Way place connecting the Atlantic and the Pacific oceans and have a control over the central communication system of the Eurasia. The Russian researcher A.F. Panarin states that the USA cannot maintain his hegemony longer without connecting the China and India [9, p. 42]. As the China gets power, Japan becomes more important for the USA. The USA needs a new powerful companion for creating the new world shape. That's why he strengthens the cooperation with Japan on the security in the Eastern Asia, the unity with Japan remains the primary policy of the USA in the Asia and the USA supports the claim of Japan for election as a member of the Security Nation. Z. Bzejinskiy writes about that: "As one of the economically developed countries, Japan doesn't take the advantage of being its potential of leadership, he doesn't tend to be a regional dominant state, he prefers to lead a policy under dependency of the USA. The role of the USA on maintaining the security in the Far East depends on relationship with Japan. The USA which is in need of the powerful companion for creating the new shape of the world, strengthens the security relationship with Japan in the Eastern Asia, actively demonstrates for gaining powerful companions [15, p. 61]'. Along with the strong diplomatic and economic relationships between two countries, assignment of the Japan as a strategic companion indicates the support of the USA to Japan [14]. It should be noted that the USA pushed forward the idea of including Japan and Germany to the permanent 
membership of the Security Council on 1970. It has importance for the USA both for increasing the number of his companions in the Security Council and decreasing the cost of the capital spending for the UN. Z.Bjezinskiy writes: "By making strong relationships with the USA on solving the global problems Japan can become a state with the power to influence in a world level. The USA administration should help to Japan on this. The USA-Japan agreement on free trade dealing with making common economic place can strengthen the relationship between the two countries. By making close relationship with Japan the USA can stop the trials of China in the region [15, p. 247].

The economic strategy is one of the priorities of the modern policy of the USA and the exploration of the hydrocarbon sources of the Caspian sea makes the Southern Caucasus one of constituent of the USA's geopolitics of Caspian region. The same time, one of the aim of the USA in the Southern Caucasus policy is to displace Russia from the region as a geopolitical opponent. Considering the foreign policy of Southern Caucasus of the USA to be the policy concerning to the Caspian region, the Azerbaijani researcher E.Nasibov writes that the USA leading its Southern Caucasus policy in 3 directions: 1. The USA builds direct relationships with the region countries. 2. Takes advantage of the assistance of the international organizations of the Europe and the leading governments of the Europe for implementing its strategy in the region. 3. Takes advantage of the potentials of Turkey in the region [2, p. 29]. The USA gives priority to all directions of international relationship in the Southern Caucasus, especially in Azerbaijan. In the conversation of the president Ilham Aliyev with the ex-Security council of the USA Zbignev Bjezinskiy and its followers Bzejinskiy explained the reason of his frequent visit to Azerbaijan as following: It is not coincidence that we have chosen the Azerbaijan republic in this region as the primary partner of the USA. We admit that Azerbaijan is an important country for the USA and we understand that well [1, p. 36].

One of the priorities of the USA's foreign policy is expansion of the NATO towards the East. As the borders of the NATO expanded, the authority of the USA in the Europe increased. Similar to European Union, joining the central European countries, Baltic Countries and Ukraine to the NATO is within the interests of the USA. The same time, European countries are reasonably dependent of the USA on insurance of their security. H.Kissinger considers that, the USA will have an integrating role in the XXI century international system although 6 power center exist in the world: the USA, Europe, China, Japan, Russia and India [4, p. 14]. The Russian researcher A. D. Bogaturov states that the aim of the USA in the policy of Europe to be the security and the aim of Near and Middle East, Caspian sea, Central Asia policy to be the environmental security, the aim of the Russia, Japan, Koreya, China and Indian policy to be the former and new strategical interests [10, p. 362].

One of the leaders of the EU - Germany keeps its global influence by means of this union. He is the main counterpart of the USA, the loyal partner of him, an important military base and a close contributor in the intelligence field. The USA supports the idea of Germany being a permanent member of the Security Council. Bjezinskiy writes about that: "In order to achieve the USA leadership in Europe the Germany leadership in the Europe should be supported. Germany supports the formula of "forgiveness + security $=$ Europe + America". According to this formula Germany is the main partner of America in Europe [15, p. 80]. "Strengthening of the military forces, strengthening of the partnership with the governments supporting its foreign policy, leading more acute policy against those who might be perilous for him, identification of its interests in relationships with transition type state organs, former opponents and partners in the matters related 
with the other countries, strengthening its global position in the bankrupt countries where different dictators are hegemons, although he pretends to be against that, maintaining the nuclear weapon and modernize it are the main priorities of the foreign policy of the USA.

Currently, the USA and Russia using veto against the decisions of the UN for the benefit of the own geopolitical interests, making inputs to the other government's internal affairs, violating the international law norms, the weakness of the UN on resolving the member nations conflicts can lead to the collapse of this organization as well. The veto right of the permanent members is one of the biggest gaps of the activity of the Security Council. This power of veto made the organization non-democratic one, turned it to the discussion club. The permanent members take advantage of the veto right as a political tool on the diplomatic and political struggle against each other. The aim of giving veto right to the permanent members of the Security Council was setting up the principle of unity between hegemon states when the UN was established. Although he supported the veto power himself, the president of the USA F.Roosevelt stated that the American people and Senate will not support this proposal as the veto right of the power states might break the security of the smaller states [12, p. 433-434]. But the USA uses the right of veto to realize the NATO centralism policy and Russia uses it for implementing its intentions in the former soviet countries. Out of the Security Council all permanent members The USA's status is different, which finances the UN more than others. The USA might lose its power and especially its economic dominance, but it is still considered as a super power. Some permanent members like Great Britain, France and Russia doesn't have that kind of advantage. Taking over the decision making process of UN by the USA, interfering the internal jurisdiction matters of the other states, violating the international law norms could lead to the collapse of the UN which is already losing its reputation. As it is known, the process under name of "Arabian spring" is directed to occupation of the Near and Middle East which situated in the advantageous geographicpolitical location and are rich with oil. The intervention of the USA into the internal affairs of Iraq, Afghanistan, Egypt, Libya, Syria and Yemen confirmed that the USA tends to control the world alone. His strategic interests are above all. The USA tends to resolve the conflicts in the regions through the NATO in favor of own interests taking advantage of the regional agreement right given by 52th paragraph of the Charter as the UN doesn't have enough military force. The USA and Great Britain proposed the Security Council to submit a different resolution to get a permission for military attack to Iraq. But the USA, Great Britain and Australia started the war against to Iraq without having consent of the Security Council and international community. One year after the war beginned Kofi Annan called for illegal infestation of Iraq and claimed that the Security Council will identify the consequences of not fulfilling the commitments by Iraq [13, p. 23]. Kofi Annan several times announced that the occupation "doesn't comply with the UN charter". Later on it was revealed that the main reason to start the war was Iraq having the weapons of mass destruction. But the Security Council didn't adopt any resolution condemning the USA and Great Britain's actions. For the permanent members of the Security Council would use a veto power against such a decision. The same time, potential of any member, especially the USA to leave the UN would be a serious blow to his legitimacy.

Recently the USA supports the defense of the sovereignty right of the UN states and having reforms in the organization with this purpose. The USA is also supporting the UN reforms. The 72th session of the UN General Assembly was held on 19-25 September 2017. 120 government heads, foreign ministers, diplomatic representatives attended in 
this session. The meeting dedicated to the UN reforms was held by the initiative of the USA. The USA president Donald Trump in his speech stated that the Secretary General Antonio Guterreshin supports the initiatives of reforms. 120 member states signed the declaration of supporting the UN reforms together with the USA. D.Trump stated that the efficiency of the UN activity is dependent of the dependency of the governments, the international right norms must be followed, the rule of law must be accepted, the sovereignty of the nations must be respected. We support the UN ensuring the sovereignty, security, development of all the countries [3].

Currently the USA's interests in Asia conflicts with the interests of any country tending to get domination in the region, especially of Russia. With this regards $\mathrm{H}$. Kissinger writes that, the main principles of the Asia policy of the USA are: Firstly, the interests of America conflicts with interest of any country tending to get dominance in the region. Secondly, for the USA the best way of defending the Asia from any threat is the existence of powerful Asian countries with the military superiority to lead a foreign policy coinciding with the intentions of the USA. Thirdly, the union with Japan remains to be the main policy of the USA in Asia. Japan has to understand that he doesn't have an important ally in Asia rather than the USA. The fourth, it is necessary to lead a close dialogue with India which can have influence on the events going on the Islamic world. In the current situation the interests of India conflict with the USA's interests of Eurasia. Fifth, China-USA relationships can be determined by the USA. These relationships should be in favor of the common interests. The sixth, the relationships with Korea should be adjusted. Seventh, the limitation of the nuclear weapon in the interest of the USA and to involve the Asia states to this process as well. The USA should have the clear policy in Asia in order to take an active part on control of the world. The USA should participate in this region but shouldn't have a dominant affection. He must have a crucial role on preventing different threats without staying in the center of the conflicts [7, p. 172-173].

Russia on its turn doesn't stop the claims of recovering the domination over the new independent states. Russia tries to benefit to ensure its geopolitical, geo-economic and other interests by taking advantage of mediation mission in the resolution of the Southern Caucasus conflicts and Nagorno-Karabakh conflict created by Armenia's military aggression. Russia breaks the territorial integrity of Ukraine by merging Crimea to itself and by not recognizing the independency of Abkhazia he breaks the integrity of territory of Georgia, tries to take over the conflict in Moldavia Transdniester region. Mediating between the government and separatist organizations, Russia in fact has many own interests. This new condition itself also makes necessary to carry out reforms in the UN. Each action of the UN should be for the favor of the defense of peace and security, to stop the conflicts and to prevent Americanism, NATO-centrism and intentions of Russia to build its empery in the former Soviet countries. Russia's vetoing to adoption of the resolutions of sovereignty and territorial integrity of these countries confirms that veto right breaks the equality principle of the states in the UN. Russia doesn't deny his claims and tends to recover his reputation within the former Soviet Union region and tries to hinder the development of new independent countries. Russia tries to achieve this by means of historically traditional methods such as crating ethnic, religious conflicts. Similar to the USA Russia also takes advantage of the UN for protection of its own interests. It is no coincidence that the USA and Ukraine didn't support plan of Russia about deployment of the UN peacekeepers in Donbas [11]. 
Although the Crimea problem has been discussed in the Security Council 7 times, the final resolution couldn't be adopted due to not achieving the unique consent between the permanent members. Despite of the fact that 13 states voted in the meeting on 15 th of March 2014, the resolution was not adopted because Russia vetoed that decision. The UN representative of the USA Samantha Power described the imposing veto by Russia: "Russia has got veto right for resolutions of the Security Council of the UN. But it doesn't have a right to veto the truth [16]." France representative of the UN Gerard Araud also stated that he doesn't support the position of Russia on Crime problem [16]. On 27th of March the General Assembly adopted a resolution about the territorial integrity of Ukraine [17]. In this resolution, the objection to actions of breaking the territorial integrity of Ukraine has been unfolded. 58 states out of 100 participating in the General Assembly didn't support the position of Russia. 10 states defended the position of Russia including Armenia. Due to not having a veto right for the resolutions of the General Assembly being different the resolutions of the Security Council, Russia couldn't veto the mentioned resolution. Thus, the UN did not recognize the integration of the Crimea into Russia. Although the General Assembly's recommendation is of a recommendatory character, it warns Russia that it violates international law.

Not agreeing with the NATO centralism policy Russia prefers the UN for the security in the continent and prefers alone control or the UN for "resolution" of the former soviet region conflicts. The Southern Caucasus remains in the focus of attention of Moscow with regards of insurance of the national security of Russia. Its mediation on adjustment of the region conflicts, co-chairing in the Minsk group of the UN or its zeal on sending the peacekeepers of Commonwealth of Independent States to the conflict region is also explained by this. After the collapse of the USSR, the USA got a great influence in the Southern Caucasus along with Russia. Russia gives priority to Armenia among the Southern Caucasus states and makes agreement with him on military. Russian researcher N. Nartov writes: "U.S. assistance to the development of Ukraine, Azerbaijan, and Georgian republics aimed at weakening Russia's centralization policy [8, p. 268]."

Russian researchers S. Jilchov and I. Zonn write: "One of the main tools of the foreign policy of the USA is applying pressure on the regions under the pretext of developing the human rights and democracy [5]." A divergence existing between the researchers of the USA on explanation lied in the reason of the USA assisting the new independent countries. Most of the American researchers consider that the USA doesn't have strategic interests in the middle Asia and Caucasus region which don't have such a large energy resources and they state the USA policy in this region directed to strengthening of democratic institution, research of the energy resources and resolution of the conflicts in the region [6, p. 241]. Z. Brzezinski writes: "The USA assists the new independent countries in order to prevent Russia to become a powerful state again [15, $\mathrm{p}$. 242]". Russia refers to the compactness of the Security Council and considers maintaining the Charter status of the existing permanent members to be necessary with regards to expansion of the Security Council membership.

\section{Література}

1. Oliyev İ.H. İnkişaf - məqsədimizdir:18 kitabda, 2-ci kitab / I. Oliyev. - Bakı:Azərnəşr, 2009. $432 \mathrm{~s}$

2. Nəsibov E.M. ABŞ və Türkiyənin Qafqaz geosiyasi regionunda strateji maraqları və Azərbaycan Respublikası / E. Nəsibov. - Bakı:Çıraq, 2006. - 312 s.

3.Выступление Дональда Трампа на Генеральной Ассамблее ООН [Електронный ресурс]. Режим доступа: https://www.golos-ameriki.ru/a/president-trump-speech-at-unga/4035236.html - Дата обращения: 19.09.2017. - Название с экрана. 
4. Ашенкмпаф Н.Н. Геополитика: Антология / Н.Ашенкампф, С.Погорельская. - М.: Академический Проект Культура, 2006, 1004 с.

5. Жильцов С. С. США в погоне за Каспием / С. С. Жильцов, И. С. Зонн. - М.: Международные отношения, 2009. - 200 c.

6. Жильцов С. С. Геополитика Каспийского региона / С. С. Жильцов, И. С. Зонн, А. М. Ушков. - М. : Международные отнощения, 2003. - 280 с.

7. Киссинджер Г. Нужна ли Америке внешняя политика? / Г.Киссинджер. - М.: Ладомир, 2002. $-352 \mathrm{c}$.

8. Нартов Н.А. Геополитика: Учебник для вузов / Н.Нартов. - М.: Единство, 2003. - 439 с.

9. Панарин А. Ф. Стратегическая нестабильность в XXI веке / А. Панарин. - М.: Алгоритм, 2003. $-450 \mathrm{c}$.

10. Современная мировая политика: Прикладной анализ /Отв. Ред. А. Д. Богатуров. - М.: Аспект Пресс, 2010. - 592 с.

11.США и Украина не поддержали российских план по миротворцам в Донбасе [Електронний ресурс]. - Режим доступа: https://tvzvezda.ru/news/vstrane_i_mire/content/201709180759-2qqe.htm. - Дата обращения: 18.09.2017. - Название с экрана.

12. Уткин А. И. Дипломатия Франклина Рузвельта / А. Уткин. - Свердловск: Издательство Урал. Университета, 1990. - 544 с.

13. Okhovat S. The United Nations Security Council: Its Veto Power and Its Reform. CPACS Working Paper No. 15/1December 2011 / S. Okhovat. - Australia: The Centre for Peace and Conflict Studies, 2012. $-74 \mathrm{p}$.

14. Bahar Bakir Birleșmiș Milletler Örgütü’nde Sanc1lı Reform Süreci [Electronic Resource]. Mode of Access: http://www.tasam.org/trTR/Icerik/285/birlesmis_milletler_orgutunde_sancili_reform_sureci (last access: 18.09.2017) - Title from the Screen.

15. Бжезинский 3. Великая шахматная доска (Господство Америки и его геостратегические императивы) / З.Бжезинский. - М.: Междунар. отношения, 1998. - 255 с.

16. Споры по Крыму в Совбезе ООН: США говорили о санкциях, а Россия - о правах [Электронный ресурс]. - Режим доступа: glavred.info/politika/spory-po-krymu-vsovbeze-oon-sshagovorili-o-sankciyah-a-rossiya-o-pravah-274140.html - Дата обращения: 15.03.2014. - Название с экрана.

17. UN General Assembly adopts resolution affirming Ukraine's territorial integrity [Electronic Resource]. Mode of Access: http://web.archive.org/web/20160304092536/http://news.xinhuanet.com/english/world/201403/28/c_126325576.htm ( last access: 28th March 2014). - Title from the Screen.

\section{References}

1. ALIYEV, İ. (2009) İnkishaf-megsedimizdir: 18 kitabda, 2-ci kitab, Baki:Azerneshr.

2. NESIBOV, E. (2006) ABSH vo Turkiyenin Qafqaz geosiyasi regionunda strateji maraqlari vo Azerbaycan Respublikasi. Baki:Çıraq.

3.Vistuplenie Donalda Trampa na Generalnoy Assambleye OON [Online]. Available from: https://www.golos-ameriki.ru/a/president-trump-speech-at-unga/4035236.html [Accessed: 19th September 2017].

4. ASHENKAMPF, N., POGOREL'SKAYA, S. (eds.) (2006) Geopolitika: Antologiya. M.:Akademicheskiy Proyekt Kultura.

5. JILCHOV, S., ZONN, I. (2009) SSHA v pogone za Kaspiyem. M.: Mejdunarodnie otnosheniya.

6. JILCHOV, S., ZONN, I. \& USHKOV, A. (2003) Geopolitika Kaspiyskogo regiona. M.: Mejdunarodnie otnosheniya.

7. KISSINDJER, G. (2002) Nujna li Amerike vneshnyaya politika? M.: Ladomir.

8. NARTOV, N. (2003) Geopolitika: Uchebnik dlya vuzov M.: Edinstvo.

9. PANARIN, A. (2003) Strategicheskaya nestabilnocti v XXI veke. M.: Algoritm.

10. BOGATUROV, A. (ed.) (2010) Sovremennaya mirovaya politika: Prikladnoy analiz. M.: Aspekt Press.

11. SSHA i Ukraina ne dodderjali rossiyskix plan po mirotvorcham v Donbase [Online]. Available from: https://tvzvezda.ru/news/vstrane_i_mire/content/201709180759-2qqe.htm [Accessed: 18th September 2017].

12. UTKIN, A. (1990) Diplomatiya Franklina Ruzvelta. Sverdlovsk: Izdatelstvo Ural. Universiteta. 
13. OKHOVAT, S. (2012) The United Nations Security Council: Its Veto Power and Its Reform. CPACS Working Paper No. 15/1December 2011. Australia: The Centre for Peace and Conflict Studies.

14. Bahar Bakir Birleshmish Milletler Örgütünde Sancili Reform Süreci 21.07.2005. [Online]. Available

from:

http://www.tasam.org/trTR/Icerik/285/birlesmis_milletler_orgutunde_sancili_reform_sureci [Accessed: 18 September 2017]

15. BJEZINSKIY, Z. (1998) Velikaya shakhmatnaya doska (Gospodstvo Ameriki I ego geostrategicheskaya imperativi) M.: Mejdunar. otnosheniya.

16. Spori po Krimu v Sovbeze OON:SSHA govorili o sankchiyakh, a Rossiya - o pravash. [Online]. Available from: glavred.info/politika/spory-po-krymu-vsovbeze-oon-ssha-govorili-o-sankciyah-a-rossiyao-pravah-274140.html [Accessed: 15th March 2014].

Available

17. UN General Assembly adopts resolution affirming Ukraine's territorial integrity. [Online]. http://web.archive.org/web/20160304092536/http://news.xinhuanet.com/english/world/201403/28/c_126325576.htm [Accessed: 28th March 2014].

Надійшла до редколегії 09.10.2017

Раміла Бахлул Дадашова, доцент, доктор історичних наук, начальник відділу Кавказької політики Інституту кавказьких досліджень НАНА, Азербайджанська Республіка.

\section{ЗОВНІШНЯ ПОЛІТИКА США: ВІДНОСИНИ США - РОСІЇ В РАМКАХ БЕЗПЕКИ ООН}

Анотація. У статті аналізуються пріоритети зовнішньої політики США. Автор зазначає, що при формуванні нової системи міжнародних відносин США не лише прагнуть зберегти гегемонію, але й прагнуть зміцнити свої позииії в регіонах світу, які $\epsilon$ економічно багатими та стратегічно важливими. Пріоритетами зовнішньої політики США $\epsilon$ посилення колись відомого «шовкового шляху», щзо з'єднує Атлантику та Тихоокеанський регіон, контроль над центральною системою комунікації Євразії, розширення НАТО на Схід. США підтримують Німеччини та Японію, будучи постійним членом Ради Безпеки, для забезпечення безпеки в СС та на Далекому Сході.

Сьогодні інтереси США в Азї суперечать інтересам будь-якої країни, яка прагне отримати домінування в регіоні, особливо Росії. США та Росія, які застосовують вето проти рімень ООН на користь власних геополітичних інтересів, втручаються у внутрішні справи інших урядів. Слабкість ООН щодо врегулювання конфліктів між державами-членами, може призвести до краху ичіє̈ організації. Нещзодавно США підтримали захист суверенних прав держав-членів ООН та проведення реформ в організачії з иүією метою.

Ключові слова: зовнішня політика США, дипломатичні та економічні відносини, право вето. 